\title{
ANAEROBIC MESOPHILIC DIGESTION OF SLUDGE WITH EXTRA-THERMOPHILIC AND HIGH PH PRE-TREATMENT
}

\author{
Anne Menert \\ Tallinn Technical University, Estonia \\ Ergo Rikmann \\ PIC Estonia Ltd., Estonia \\ Merje Michelis \\ Stockholm Environmental Institute Tallinn Centre, Estonia \\ Tarmo Vaalu \\ Viktoria Blonskaja \\ Raivo Vilu \\ Tallinn Technical University, Estonia
}

\begin{abstract}
In this study different methods of sludge pre-treatment with elevated temperatures and $\mathrm{pH}$ have been selected for investigation. Five sets of sludge samples were pretreated as follows: heating at $70^{\circ} \mathrm{C}$ for $30 \mathrm{~min}$, at $80^{\circ} \mathrm{C}$ for $20 \mathrm{~min}$, at $90^{\circ} \mathrm{C}$ for $10 \mathrm{~min}$, at $100^{\circ} \mathrm{C}$ for $5 \mathrm{~min}$ and $\mathrm{NaOH}$-treatment ( $\mathrm{pH} 12$ for 4 hours). For comparison a sample from Tallinn WWTP (3:1 mixture of primary (dry solids $5.2 \%$ ) and activated sludge (dry solids $0.5 \%$ )) was used. Extra-thermophilic pre-treatment increased the degree of hydrolyses of sludge, enabling the following anaerobic digestion process to proceed faster than that of raw sludge. However, extra-thermophilic pre-treatment was insufficient for removal of nitrogen and phosphorous. Nitrogen can be easily solubilized during extra-thermophilic pre-treatment but solubilization of phosphorous occurs only through digestion. The production of biogas during anaerobic digestion was also dependant on the quality of the input of pre-treated sludge. The highest cumulative volume of biogas $(124 \mathrm{~mL} / \mathrm{g}$ COD added) was achieved by pre-treatment at $80^{\circ} \mathrm{C}$. The percentage of mineralization of pretreated sludges on mesophilic digestion was the highest with $90^{\circ} \mathrm{C}$ sample $-65.9 \%$.
\end{abstract}

\section{KEYWORDS}

Anaerobic; Digestion; Extra-thermophilic; High pH; Mesophilic; Pre-treatment; Sludge. 
KALMAR ECO-TECH'03

Bioremediation and Leachate Treatment

KALMAR, SWEDEN, November 25-27, 2003

\section{INTRODUCTION}

Sludge handling represents $30-40 \%$ of the capital cost and about $50 \%$ of the operating cost of many wastewater treatment facilities [1]. Hence several pre-treatment methods are used and investigated in order to make sludge handling processes more cost-effective - to achieve a shorter sludge retention time in an anaerobic digester, to increase the biogas yield etc, also to achieve a better hygienization effect. Study and application of anaerobic thermophilic hygienization and other pre-treatment methods of residual sludge would allow the use hygienized and stabilized sludge in agriculture. In Estonia anaerobic stabilization of residual sludge has been applied only in Tallinn and Narva WWTPs. Our previous studies have indicated that thermal pre-treatment (as the first stage of anaerobic digestion process) is the optimal method, considering the requirements for energy, hygienization effect and yield of mineralization of organic matter $[2,3]$. Thermal pretreatment was the most efficient method as to additional solubilization of total suspended solids (TSS) and their subsequent anaerobic decomposing. The conditions leading to the greatest increase in the degree of biodegradation and in gas production, were anaerobic thermophilic $\left(+65^{\circ} \mathrm{C}\right)$ pre-treatment with hydraulic retention time (HRT) 15 hours and extra-themophilic $\left(+70^{\circ} \mathrm{C}\right)$ pre-treatment with HRT 0.5 hours $[3,4]$. About $50 \%$ of total organic matter of sludge was solubilized and a high specific biogas production (around $0.5 \mathrm{~m}^{3} / \mathrm{kg}$ COD added) was obtained [2].

In the literature, various pre-treatment techniques have been reported in recent years. Kim et al. compared several pre-treatment methods - thermal $\left(121^{\circ} \mathrm{C}\right.$ for $\left.30 \mathrm{~min}\right)$, chemical $(7$ $\mathrm{g} \mathrm{L}^{-1} \mathrm{NaOH}$ addition), ultrasonic $(42 \mathrm{kHz}$ for $120 \mathrm{~min})$ and thermochemical $\left(121^{\circ} \mathrm{C}\right.$ for $30 \mathrm{~min}, 7 \mathrm{~g} \mathrm{~L}^{-1} \mathrm{NaOH}$ addition) methods [5]. The latter, conditioning of sludge using a basic agent at elevated temperature, was found to be the most favorable as it had the best effect on COD solubilization (up to $80 \%$ ) and the highest increase in biogas production (up to $37.8 \%$ ). All pre-treatment methods reduced particle size, especially thermal and thermochemical pre-treatments. The level of soluble protein was also most increased after chemical and thermochemical pre-treatment [5]. Also by data of Vlyssides et al thermochemical treatment at $\mathrm{pH} 10$ and $\mathrm{t} \geq 80{ }^{\circ} \mathrm{C}$ increased the solubilization of organic matter (COD) significantly until the eighth hour of hydrolysis, when about $80 \%$ of solubilization was achieved [1].

Gavala et al investigated the effect of pre-treatment at $70^{\circ} \mathrm{C}$ on the subsequent mesophilic $\left(37^{\circ} \mathrm{C}\right)$ or thermophilic $\left(55^{\circ} \mathrm{C}\right)$ anaerobic digestion of primary and secondary sludges [6]. The pre-treatment step showed very positive effect on the methane potential and production rate upon subsequent thermophilic digestion of primary sludge. Pre-treatment of secondary sludge followed by mesophilic and thermophilic digestion influenced mostly methane production rate, whereas methane potential was positively influenced only if mesophilic digestion followed. The higher methane potential of primary sludge as compared to secondary sludge and the different effects of pre-treatment in each case were explained by the different composition of two types of sludges. Primary sludge is 
KALMAR ECO-TECH'03

Bioremediation and Leachate Treatment

KALMAR, SWEDEN, November 25-27, 2003

composed mainly of carbohydrates $(55 \%)$ while secondary sludge consists for the most part of bacterial cells, characterized by higher protein content $(36 \%)$. The integrity of bacterial cells impedes biological decomposition of secondary sludge as by theory thermal pre-treatment should destroy the cell walls and make the proteins accessible for biological degradation [7]. The presented results suggest that selection of pre-treatment duration as well as temperature of the subsequent anaerobic step for sludge stabilization should depend on the composition of the sludge.

Lafitte-Trouqué \& Forster found that although ultrasound $(23 \mathrm{kHz}, 47 \mathrm{~W}, 90 \mathrm{~s})$ and $\gamma$ irradiation ( $90 \mathrm{~s}, 500 \mathrm{krad})$ substantially increased the concentrations of soluble organic matter, no significant improvement was observed on the anaerobic digestion of thickened waste activated sludge neither at mesophilic nor at thermophilic temperatures [8]. However, a significant improvement was seen in the hourly biogas production study at the thermophilic temperature with an HRT of 10 days over the first eight hours. $\gamma$ Irradiation gave better disinfecting effect than sonification by means of reduction of faecal coliforms. Low frequency and high-intensity ultrasonic treatment of sewage plant sludge disrupts flocs and lyses bacterial cells. This results in efficient release of free and interstitial water containing organic matter and therefore reduction in particle volume. Gonze et al mention that for a given dissipated energy level, the greater is the initial volume fraction, the greater is the quantity of solubilized organic matter. [9]. The limiting factor is the probability of contact between the cavitation bubble and a microorganism. However, carrying out ultrasound treatment directly upstream of a settling or filtration step seems impossible because ultrasound has a drastically deleterious effect on the settleability and filtration parameters. [9].

The main potential advantages expected for the two-step anaerobic treatment (with pretreatment) are better control of both acidogenic and methanogenic steps; smaller size of first stage reactor, higher suspended solids removal efficiency and higher methanogenic specific activity in the second reactor. Thus the objectives of this study were:

-to determine the effects of different pre-treatment methods on the digestibility

-to determine the compositional changes during anaerobic mesophilic digestion.

\section{MATERIALS AND METHODS}

Five sets of sludge samples were pretreated as follows: heating at $708 \mathrm{C}$ for $30 \mathrm{~min}$, at $808 \mathrm{C}$ for $20 \mathrm{~min}$, at $90 \mathrm{BC}$ for $10 \mathrm{~min}$, at $1008 \mathrm{C}$ for $5 \mathrm{~min}$ and $\mathrm{NaOH}$-treatment $(\mathrm{pH} 12$ for 4 hours). For high $\mathrm{pH}$ adjustment sodium hydroxide $(\mathrm{NaOH})$ is more effective than lime [10] and thus we used it for alkaline pre-treatment. For comparison a sample from Tallinn WWTP (3:1 mixture of primary (dry solids $5.2 \%$ ) and activated sludge (dry solids $0.5 \%$ ) was used (see Table 1).

Testing of the effectiveness of pre-treatment was performed in batch mode with mesophilic digestion - $75 \%$ pre-treated sample $+25 \%$ anaerobic sludge from working methane tank. After pre-treatment process all the reactors were placed into thermostat to mesophilic temperature $(36 \pm 18 \mathrm{C})$. The laboratory-scale equipment is shown in Figurel. 
It consisted of five $1000 \mathrm{~mL}$ flasks equipped with outlets for sampling and gas collection. Each reactor was connected to gas collection bottle that was used to record the daily biogas production volume. Cumulative biogas production during the 24-day period was used to evaluate the digester performance under different operating conditions.

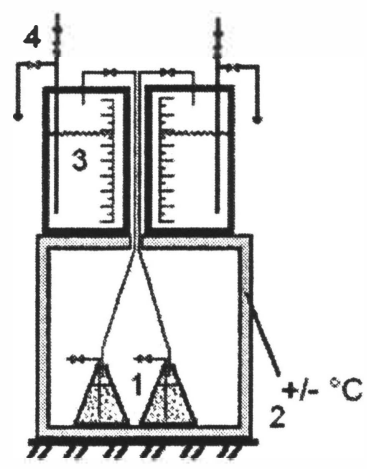

Figure 1. Scheme of anaerobic digester. 1-anaerobic reactors, 2-thermostate, 3-gas collector, 4-gas sampling point.

Table 1. Composition of residual sludge (raw sludge)

\begin{tabular}{lcccc}
\hline \multicolumn{1}{c}{ Sample } & $\mathrm{COD}, \mathrm{mg} \mathrm{O}_{2} \mathrm{~L}^{-1}$ & $\mathrm{VFAs}, \mathrm{mg} \mathrm{L}^{-1}$ & $\mathrm{P}_{\text {tot }}, \mathrm{mg} \mathrm{L}^{-1}$ & $\mathrm{NH}_{4}-\mathrm{N}, \mathrm{mg} \mathrm{I}$ \\
\hline Raw sludge suspension & 40000 & - & 835 & 50 \\
\hline $\begin{array}{l}\text { Raw sludge supernatant } \\
\text { (3 000 mm, } 10 \mathrm{~min} \text { ) }\end{array}$ & 6250 & 977 & 51.8 & 140 \\
\hline
\end{tabular}

From raw sludge and pretreated sludges the following chemical analyses were performed at the beginning and at the end of mesophilic digestion, according to the standard methods [11]:

a) in sludge suspension - mineralization, $\mathrm{N}_{\text {tot }}\left(\mathrm{NH}_{4}-\mathrm{N}\right), \mathrm{P}_{\text {tot }}, \mathrm{COD}$;

b) in the liquid phase (supernatant, $3000 \mathrm{rpm}, 10 \mathrm{~min}$ ) - mineralization, VFAs, $\mathrm{N}_{\text {tot }}\left(\mathrm{NH}_{4}-\mathrm{N}\right), \mathrm{P}_{\text {tot }}, \mathrm{COD}$, total dissolved solids (TDS);

At the end of the experiment gas samples were taken for analyses of $\mathrm{CH}_{4}, \mathrm{CO}_{2}, \mathrm{H}_{2}, \mathrm{NH}_{3}$ on FT-IR spectrometer Gasmet Dx 4005. 


\section{RESULTS AND DISCUSSION}

\subsection{Pre-treatment}

The effect of pre-treatment methods (thermal and chemical) is presented on the figures below. Influence of pre-treatment and mesophilic digestion on the solubilization of organic matter and biogenic compounds in residual sludge is shown in Figure 2.

The highest level of soluble compounds was released from sludge during $90^{\circ} \mathrm{C}$ thermal pre-treatment and made thus potentially available to subsequent bacterial degradation. This was observed for COD, nitrogen and phosphorus as well. Concentration of solubilized phosphorus compounds was the highest for $\mathrm{pH}$ pretreated sludge sample. With increasing solubilization of organic substances, more volatile solids (VS) become biodegradable and the amount of total dry matter decreases. From the point of view of effectiveness of sludge management this is undoubtedly a positive effect. However, solubilization of bounded nitrogen (as $\mathrm{NH}_{4}{ }^{+}$) and phosphorus may lead to a problem of crystalloid structure formation (struvite sedimentation) in the subsequent sludge dewatering process [12].

As a result of pre-treatment the concentrations of soluble COD, soluble $\mathrm{P}_{\text {tot }}, \mathrm{N}_{\text {tot }}$, and VFA increased, but concentrations of $\mathrm{P}_{\text {tot }}, \mathrm{N}_{\text {tot }}$ and COD in suspension decreased. Up to $43 \%$ degradation of organic matter (by total dissolved solids, TDS) in the subsequent mesophilic anaerobic treatment was achieved (see Figure 4).

During pre-treatment most of proteins are converted into VFAs and ammonia and as a consequence their content in reactors increased. Additional amounts of VFA-s significantly influence the further biodegradation processes. 
KALMAR ECO-TECH'03

Bioremediation and Leachate Treatment

a

KALMAR, SWEDEN, November 25-27, 2003

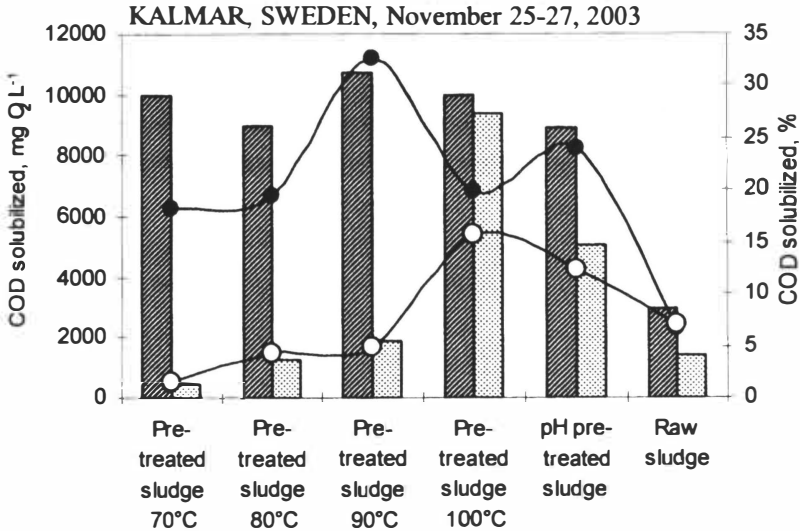

b
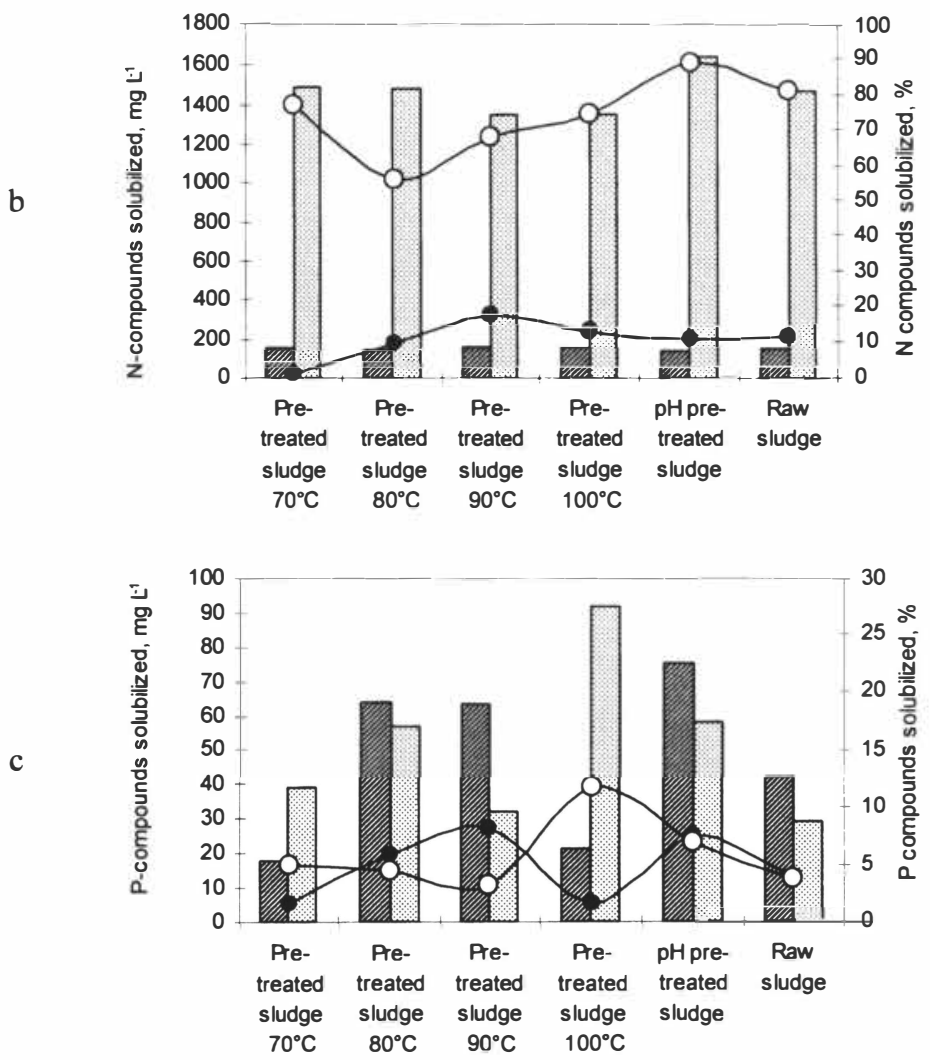

Figure 2. Influence of pre-treatment and mesophilic digestion on the solubilization of organic matter and biogenic compounds in residual sludge. 
KALMAR ECO-TECH'03

Bioremediation and Leachate Treatment

KALMAR, SWEDEN, November 25-27, 2003

$a$-solubilization of organic matter (COD), $b$-solubilization of $N$-compounds, $c-$ solubilization of P-compounds. $\square$ - day $0, \mathrm{mg} \mathrm{L}^{-1}, \square-$ day $20, \mathrm{mg} \mathrm{L}^{-1}, \bigcirc$ day 0 , $\%$, O - day $20, \%$.

\subsection{Changes during anaerobic digestion.}

Effects of anaerobic digestion on pre-treated sludge were compared with effect of anaerobic digestion on untreated sludge sample from Tallinn WWTP, mixture of primary and activated sludge. Influence of pre-treatment together with mesophilic digestion on the removal and accumulation of organic matter and biogenic compounds in residual sludge is presented in Figure 3.

During mesophilic digestion, the content of VFAs in the medium decreased, with exception of samples pretreated at $1008 \mathrm{C}$ and by elevated $\mathrm{pH}$. Taking into account the biogas production it could be suggested that occasional developments in the microbial biogeocoenosis influenced unfavorably VFA-degrading consortia in the sample pretreated at $1008 \mathrm{C}$. Another explanation could be formation of Maillard reaction products (melanoidins) [13]. At its early stages this reaction involves condensation of reducing sugars (carbonyl groups) with amino acids (free amino groups) followed by formation of Amadori rearrangement product. Depending on environmental conditions ( $\mathrm{pH}$, water content) the subsequent degradation of the latter will lead finally to formation of melanoidins - brown nitrogenous polymers, slowly degradable organic compounds.

In the pH-treated sample, the VFA degradation was inhibited throughout the experiment.

On mesophilic digestion the percentage of mineralization of pre-treated sludges is slightly higher that that of raw sludge with the exception of treatment at $908 \mathrm{C}$ (see Figure 4). It is presumable that the increase in mineralisation could occur only at the expense of organic material consumed, an approximate measure of which is the percentage of total dissolved solids (TDS) decreased during mesophilic digestion. The high value for the $\mathrm{pH}$-treated sample is brought about by the high concentration of $\mathrm{NaOH}$ used to adjust the $\mathrm{pH}$.

About $75-80 \%$ of the biogas was produced during the first 2 weeks (see Figure 5). Cumulative amounts of biogas were the highest for samples pretreated at $708 \mathrm{C}$ and $808 \mathrm{C}$, exceeding the biogas yield of non-pretreated sludge. Cumulative amounts of biogas of other sets were lower than that of non-pretreated sludge. For samples of $\mathrm{pH}$-pre-treatment and $908 \mathrm{C}$, intensive evolvement of biogas started a week later than for other sets. In the sample containing sludge pretreated at $1008 \mathrm{C}$ the biogas emission ceased at day 10 after rapid increase in the first days of the experiment. This happened probably due to the fast accumulation of eVFA-s in the medium, as shown in Figure 3. To a lesser extent, VFA-s accumulated also into the $\mathrm{pH}$-pretreated sample, which reverberated in a lesser biogas yield. It could be concluded, that the influence of thermal pre-treatment on the biogas yield is generally positive, but in self-developing micro-ecosystems of sludge the impact of uncontrollable, random factors on the microbial associations could play the decisive role for the outcome. 
KALMAR ECO-TECH'03

Bioremediation and Leachate Treatment

KALMAR, SWEDEN, November 25-27, 2003

The nitrogen and phosphorus content in the liquid phase increased after digestion. The concentration of nitrogen (soluble and suspension) was near anaerobic process inhibitory level. As it is known relative concentrations of dissolved and ionised ammonium are dictated by the system $\mathrm{pH}$. At high $\mathrm{pH}$ values unionised form of $\mathrm{N}$-ammonia dominates, and this form is more inhibitory than the ion. The inhibition level of ammonia concentration starts at $1500 \mathrm{mg} \mathrm{L}^{-1}$ [14]. Hence additional amounts of ammonia are not suitable to compensate the deficiency of nitrogen.
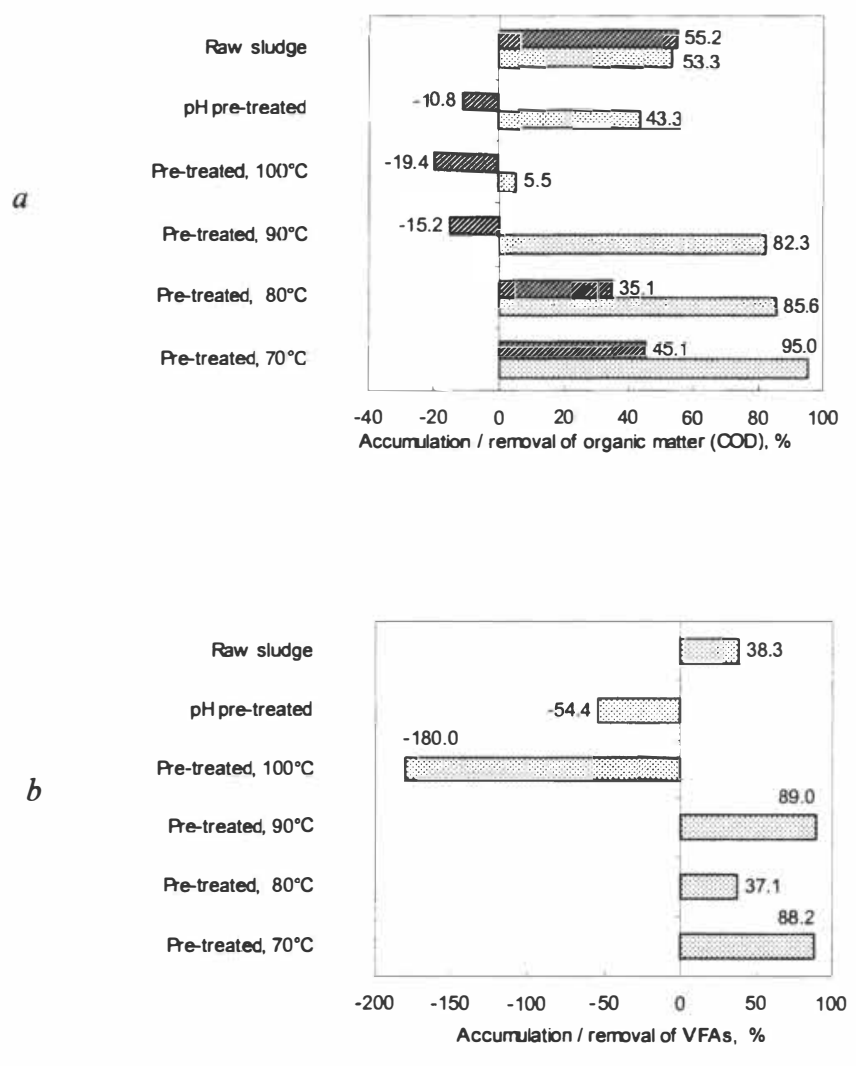
KALMAR ECO-TECH'03

Bioremediation and Leachate Treatment

KALMAR, SWEDEN, November 25-27, 2003

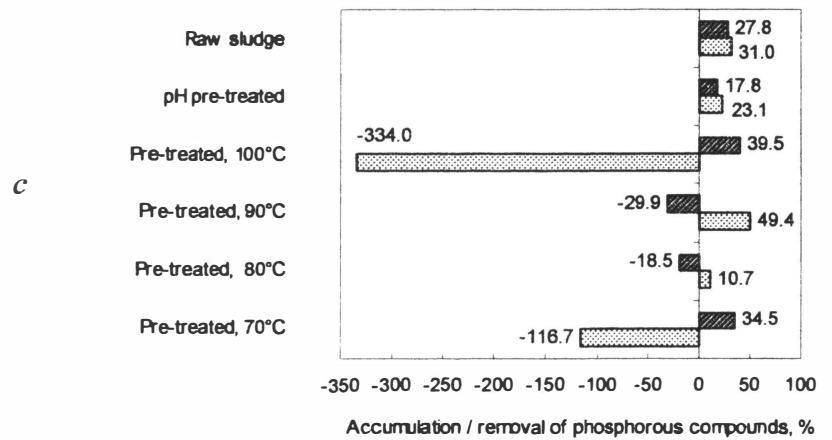

Figure 3. Influence of pre-treatment together with mesophilic digestion on the accumulation (-) / removal (+) of organic matter and biogenic compounds in residual sludge. a - accumulation / removal of organic matter (COD), baccumulation / removal of volatile fatty acids, $c$-accumulation / removal of phosphorous compounds. $\square$ from sludgetotal, \%; $\square$ from solubilized part of sludge, $\%$.

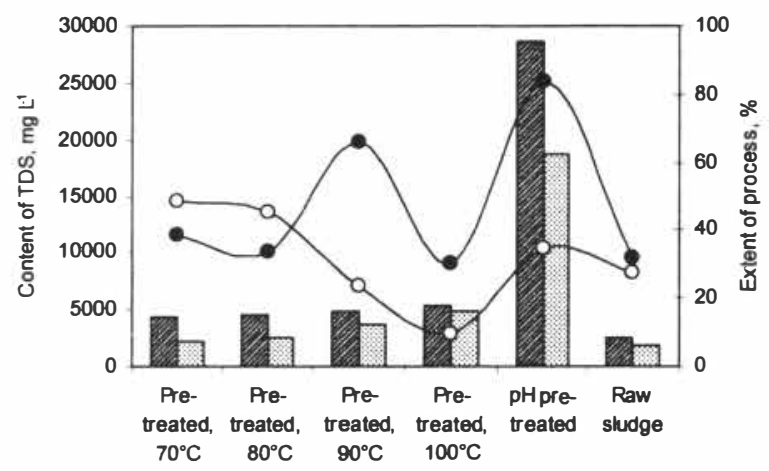

Figure 4. Content of TDS and mineralization and after mesophilic digestion. Content of TDS: - dayy 0,mg L $L^{-10} \square-$ day 20, mg L $\mathrm{L}^{-10}$, O - TDS digested after 20 days, $\%$; - mineralization after 20 days, \%.

The methane content of the biogas produced varied within a range of $25 \div 53 \%$ for different test conditions (see Table 2). Thermophilic pre-treatment at $90{ }^{\circ} \mathrm{C}$ increased the proportion of $\mathrm{H}_{2}$ and $\mathrm{CH}_{4}$ in biogas. On the basis of laboratory experiments, anaerobic thermal pre-treatment could be recommended as a perspective pre-treatment method of residual sludge for WWTPs. 


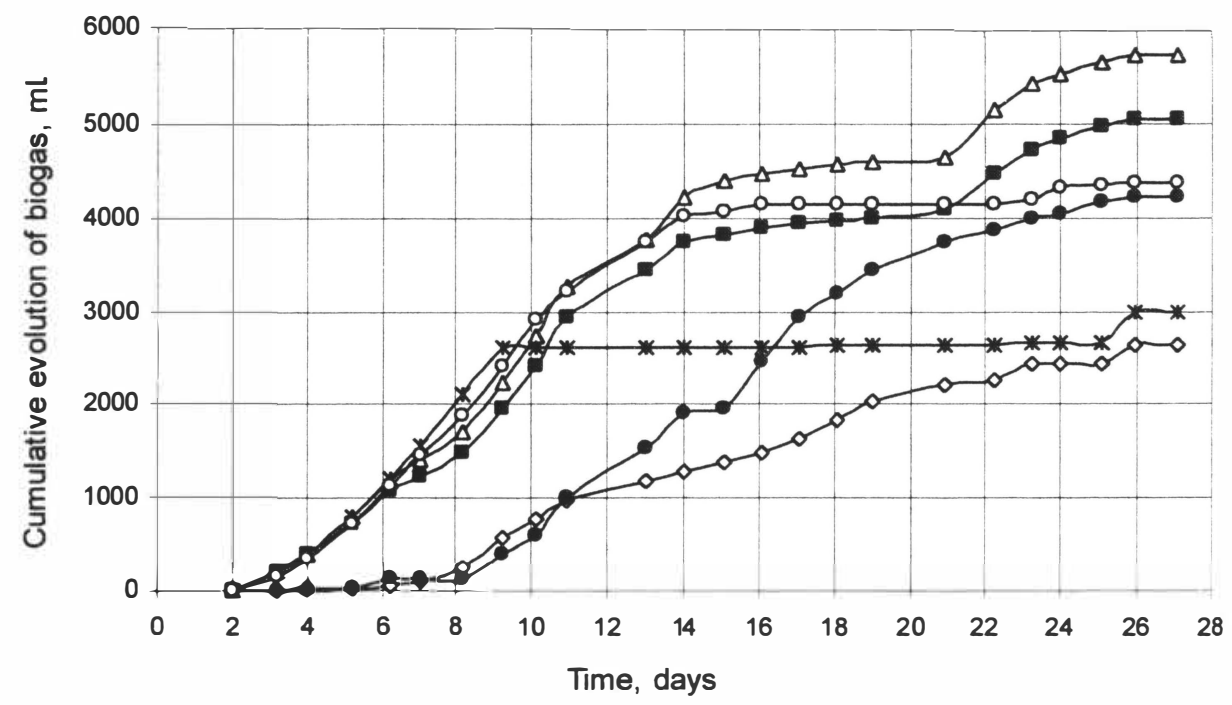

Figure 5. Cumulative evolution of biogas during mesophilic digestion of sludge samples (after pre-treatment). - at $70^{\circ} \mathrm{C}, \triangle$ - at $80^{\circ} \mathrm{C}, \bullet$ - at $90^{\circ} \mathrm{C},{ }^{*}$ - at $100^{\circ} \mathrm{C}, \diamond$ - at pH 12, O - raw sludge.

Table 2. Composition of biogas

\begin{tabular}{cccccccc}
\hline Method & $\begin{array}{c}\mathrm{H}_{2} \mathrm{O}, \\
\text { vol\% }\end{array}$ & $\begin{array}{c}\mathrm{CO}_{2}, \\
\text { vol\% }\end{array}$ & $\begin{array}{c}\mathrm{NH}_{3}, \\
\text { vol\%*10-3 }\end{array}$ & $\begin{array}{c}\mathrm{CH}_{4}, \\
\text { vol\% }\end{array}$ & $\begin{array}{c}\mathrm{H}_{2}, \\
\text { vol\% }\end{array}$ & $\begin{array}{c}\text { Total, } \\
\text { vol\% }\end{array}$ & Comments \\
\hline Pre-treated $70^{\circ} \mathrm{C}$ & 22.8 & 6.4 & 0.02 & 47.51 & 1.5 & 78.2 & additional $\mathrm{H}_{2} \mathrm{O}$ \\
\hline Pre-treated $80^{\circ} \mathrm{C}$ & 1.1 & 3.7 & 0.08 & 24.64 & 1.1 & 30.6 & \\
\hline Pre-treated $90^{\circ} \mathrm{C}$ & 25.9 & 7.2 & 0.06 & 53.42 & 2.8 & 89.4 & additional $\mathrm{H}_{2} \mathrm{O}$ \\
\hline Pre-treated $100^{\circ} \mathrm{C}$ & 31.9 & 6.4 & 0.06 & 48.73 & 2.1 & 89.2 & additional $\mathrm{H}_{2} \mathrm{O}$ \\
\hline pH pre-treated & 1.2 & 4.2 & 0.04 & 28.53 & 1.1 & 35.1 & \\
\hline Raw sludge & 28.7 & 7.4 & 0.06 & 49.87 & 1.6 & 87.6 & additional $\mathrm{H}_{2} \mathrm{O}$ \\
\hline
\end{tabular}




\section{CONCLUSION}

- The comparison of lab scale research results to industrial WWTPs data showed that single step digestion under mesophilic conditions with thermal pre-treatment $\left(+80^{\circ} \mathrm{C}\right)$ of sufficient retention time showed remarkable results. Thermal pre-treatment with short retention times decreased the retention time of mesophilic process considerably - down to 12 days.

- Using thermal pre-treatment followed by anaerobic mesophilic digestion, the methane content of biogas varied within a range of $25 \div 53 \%$ for different test conditions and the percentage of total dissolved solids (TDS) digested in 20 days was $43 \%$. Thermophilic pre-treatment at $90{ }^{\circ} \mathrm{C}$ increased the proportion of $\mathrm{H}_{2}$ and $\mathrm{CH}_{4}$ in biogas.

- Thermal hydrolysis process gives complete energy recovery, i.e. as compared to conventional anaerobic sludge treatment, more energy is produced (in the form of $\mathrm{CH}_{4}$ and $\mathrm{H}_{2}$ ) than is needed for running the sludge stabilization system.

- Thermophilic pre-treatment increases the degree of hydrolyses of sludge; anaerobic digestion of the pre-treated sludge proceeds faster than that of raw sludge. However, on mesophilic digestion the percentage of mineralization of pre-treated sludges was only slightly higher than that of raw sludge with the exception of treatment at $90^{\circ} \mathrm{C}$ $(65.9 \%)$.

- Anaerobic thermophilic pre-treatment of sludge is insufficient for removal of $\mathrm{N}$ and $\mathrm{P}$, as $\mathrm{N}$ can be easily solubilized during thermophilic pre-treatment, solubilization of $P$ occurs only during digestion. Increased concentrations of nutrients $(N, P)$ in supematant are lead back to the influent of the wastewater treatment system.

\section{ACKNOWLEDGEMENT}

The authors express their appreciation to the Estonian Science Foundation for their financial support (Grant $N^{\circ} 5653$ ). We wish to thank Mr. Karl Saar (Eesti Energia AS, Laboratory of Ecology) for performing the gas analysis and Tõnu Kurissoo (BimKemi Eesti AS) for valuable remarks.

\section{REFERENCES}

[1] Vlyssides, A.G., Karlis, P.K., 2004, Thermal-alkaline solubilization of waste activated sludge as a pre-treatment stage for anaerobic digestion. Biores. Technol. 91 (2), 201-206. 
KALMAR ECO-TECH'03

Bioremediation and Leachate Treatment

KALMAR, SWEDEN, November 25-27, 2003

[2] Blonskaja, V., Menert, A., Vaalu, T., Vilu, R., 2002, Anaerobic mesophilic digestion of sludge with pre-treatment. 3rd International Symposium Anaerobic Digestion of Solid Wastes. 18-20 September 2002, Munich/Garching, Germany, 8 pp.

[3] Blonskaja, V., Vaalu, T., 2002, Single and two-stage anaerobic mesophilic sludge digestion with thermal pre-treatment. ESWA 2002, World Environment Congress and Exhibition, Istanbul, Turkey, 8-11 July 2002. In: Appropriate Environmental and Solid Waste Management and Technologies for Developing Countries, vol 3, pp. 1463-1470.

[4] Menert, A., Blonskaja, V., Vaalu, T., Sokk, O., Mölder, H. (2001). Comparison of physical and chemical pre-treatment methods for excess sludge. $9^{\text {th }}$ World Congress Anaerobic Digestion 2001. Anaerobic Conversion for Sustainability. Antwerpen, Belgium, 2-6 September 2001. Conference Proceedings, part 1, pp. 61-66.

[5] Kim, J., Park, C., Kim, T.-H., Lee, M., Kim, S., Kim, S.-W., Lee, J., 2003, Effects of various pre-treatments for enhanced anaerobic digestion with waste activated sludge. J. Bioscience and Bioengineering. 95(3), 271-275.

[6] Gavala, H. N., Yenal, U., Skiadas, I.V., Westermann, P., Ahring, B.K., 2003, Mesophilic and thermophilic anaerobic digestion of primary and secondary sludge. Effect of pre-treatment at elevated temperature. Wat. Res. 37, 4561-4572.

[7] Kepp, U., Machenbach, I., Weisz, N. and Solheim, O.E., 1999, Enchanced stabilization of sewage sludge through thermal hydrolysis - three years of experience with full-scale plant. Wat. Sci. Tech., 42(9), 89-96.

[8] Lafitte-Trouqué, S., Forster, C.F., 2002, The use of ultrasound and $\gamma$-irradiation as pre-treatments for the anaerobic digestion of waste activated sludge at mesophilic and thermophilic temperatures. Biores. Technol. 84, 113-118

[9] Gonze, E., Pillot, S., Valette, E., Gonthier, Y., Bernis, A., 2003, Ultrasonic treatment of an aerobic activated sludge in a batch reactor. Chem. Eng. Proc. 42, 965-975.

[10] Rajan, R.V., Lin, J.G., Ray, B.T., 1989, Low-level chemical pre-treatment for enhanced sludge solubolization. J. Water Pollut. Contr. Fed. 61 (11/12), 1678-1683.

[11] Standard Methods for the Examination of Water and Wastewater. American Public Health Association. 19 ${ }^{\text {th }}$ Edition, 1995.

[12] Doyle, J.D. Parsons, S.A., 2002, Struvite formation, control and recovery, Wat. Res., 36, 3925-3940.

[13] Martins, S.I.F.S., 2003, Unravelling the Maillard reaction network by multiresponse kinetic modelling. PhD Thesis, Wageningen University, The Netherlands, $170 \mathrm{pp}$. ISBN:90-5808-823-5 
KALMAR ECO-TECH'03

Bioremediation and Leachate Treatment

KALMAR, SWEDEN, November 25-27, 2003

[14] Mata-Alvarez, J., Macé, S., Llabrés, P., 2000, Anaerobic digestion of organic solid wastes. An overview of research achievements and perspectives, Biores. Technol., 74, 3-16. 